\title{
Editorial
}

\section{Trafficking Inspiration}

It is impossible not to notice how commercialized higher education has become - that so many industry drivers are now factors in the directions and priorities of college and universities. We see it in the Starbucks at the entrance to the library; the outsourcing of non-core functions like food services, grounds-keeping and maintenance; and the external accountability and focus on reporting and return on investment. It's even evident in the research and scholarship created by faculty.

It has reached the point where innovation is integrated into the products of the university. We have seen it on the back end of the research process with technology commercialization departments in universities seeking to capitalize on the research findings - and recently, we have seen the trend spread through institutions of higher education with innovation centers ${ }^{1}$ hoping to stimulate new knowledge and new inventions.

But it is really possible to systematize creativity?

Probably the prime example of an organized and intentional effort in higher education to innovate is MIT's Media Lab. ${ }^{2}$ They have been around for decades - by now, the "innovation gene" is embedded in their culture. They have a blended approach to research and education that defies the traditional boundaries, crossing the lines between disciplines and even between academics and industry. They have been going strong since the 1980s and show no signs of stopping. With this exceptional instance of sustained innovation in academia, systematizing appears possible with the right elements and circumstances in place.

Now, you may be wondering about the title of this editorial. It is actually a mildly amusing story. A researcher with whom I work on several projects was trying to come up with a catchy name for an interactive platform he was developing. We had been throwing ideas around fruitlessly until one early morning when an especially loud motorcycle startled me out of my sleep. At the same time, a perfect name for his project came to me! I texted him with the idea and he adopted it. Not too long after that, we were brainstorming another name for a different project. I was driving home in traffic when the name just came to me. Maybe there had been a loud motorcycle in the stopand-go traffic or maybe it was just traffic in general that had become my inspiration. After all, inspiration can come from anywhere, right?

Now, these are trivial examples of a complex process but it does make one wonder about the processes, both cognitive and organizational, around innovations and creativity.

So where does creativity come from?

There is a lot of research examining this question. After all, there is a lot of money in creativity and problem-solving - not to mention substantial benefits to society.

Everett Rogers' classic work explains how ideas spread ${ }^{3}$ but it also categorizes technology adopters and addresses attributes of innovators who, according to Rogers, make up just $2.5 \%$ of the population. For Rogers, being an innovator comes with several "prerequisites":

- "Control of substantial financial resources is helpful to absorb the possible loss from an unprofitable innovation.

- The ability to understand and apply complex technical knowledge is also needed.

- The innovator must be able to cope with a high degree of uncertainty about an innovation at the time he or she adopts. 
- The salient value of the innovator is venturesomeness. He or she desires the hazardous, the rash, the daring, and the risky.

- The innovator must also be willing to accept an occasional setback when one of the new ideas he or she adopts proves unsuccessful, as inevitably happens."4

These last three facets necessary for creativity and innovation are often overlooked or, in some instances, entirely squelched. Innovation has, at its root, a questioning of the status quo and a desire for change and - if an organization discourages challenges to its established practices - it is unlikely that creativity will abound. It requires the willingness to take a risk and fail. Academic culture is built on knowledge and expertise - not a very safe environment for visible failures. This is compounded by the recent public scrutiny of higher education with regard to return on investment and accountability.

I had a recent conversation with a colleague after sending some submissions for consideration and anxiously waiting to hear whether they would be accepted. While the waiting for a decision is agonizing, the contemplation of failure is equally nervewracking. Through the course of our conversation, we were reminded of a Princeton professor's CV of Failure ${ }^{5}$ which demonstrates some spectacular failures. However, it also serves as reminder that, while not trying means not failing, it also means not succeeding.

The safe path never changed the world.

So, we should celebrate our successes but we should also celebrate our failures. As childish as it may be, the theme from the movie, Meet the Robinsons, celebrates failure and the knowledge it brings - "From failure we learn, from success not so much." Working in higher education, we understand the value of learning - and the value of learning experiences which may be painful, embarrassing, or both.

Certainly, I feel like, given my own failures, I must have learned a lot.

"Failure is not an option, it's bundled in your software." I saw this pithy yet slightly bitter comment on a t-shirt a while ago. It made me laugh out loud-mainly because it is so true.

But it also prompted me to think about the nature of failure in this regard. Certainly, we all have experiences with software acting up or breaking down on our computers, phones, cars, TVs - and even things like our refrigerators and doorbells. Many of these are addressed with patches and upgrades - which may beg the question, why didn't the company and the programmers wait until they got it right in the first place? Of course, this is really just an exasperated rhetorical question because we know when someone releases version 10.0 (or X if they're really hip), that they are already working on 11.0 (or $\mathrm{X}+$ ) to address what wasn't right in the last version. In this way, "computer upgrade" has almost become an oxymoron.

For all the complaints, however, this model-iterative design-is actually what moves us forward more quickly. It has failure built in as an important aspect-an acknowledgment that it is an important part of the process in moving forward, taking risks, and learning. However, it does tend to treat consumers more as beta testers, which can be frustrating, but can also provide them with an opportunity for input. In this context, the expectations of the consumer is often counter to the culture of the company, or even the industry.

I would also argue that, as cliché as it sounds, our lives are more defined by our failures than our successes. Honestly, I personally learn more from my failures than my successes. They have informed many of the decisions I have made and the risks I have taken. I probably take more risks than some, but they are comparatively more low stakes than others.

Our profession has an interesting relationship with failure. Maybe it is informed by the mission to be information specialists and knowledge experts. It is our job to 
KNOW - which may prompt some to be very reluctant to either admit to a mistake or to say they don't know. It is as if a librarian admitting that they don't have the answer strikes right at the core of the profession-of who we are.

However, if someone can't admit to either of those things, how can they learn or improve? How do they get better?

Organizations and individuals alike can't evolve if they don't learn from their mistakes. I am quite fond of that seemingly utopian concept of the learning organization ${ }^{6}$ that embraces innovation and risk, and reflection and learning. It has always struck me that libraries have the potential to be the ultimate learning organization. This is particularly true as the information landscape is in a state of constant flux - a situation that is not likely to change. Peter Senge's model has been around for years but it is timeless. He articulates five disciplines through which we can view academic libraries:

\section{Personal Mastery}

Senge asserts that "organizations learn only through individuals who learn." Given that the mission of academic libraries is to provide access to information, contribute to the educational and research missions of their parent institutions, and preserve information, libraries depend on the expertise of their librarians and staff.

\section{Mental Models}

Senge asserts that "...New insights fail to get put into practice because they conflict with deeply held internal practices...." This can manifest itself in comments like, "We tried that before and it didn't work," or other such references to historical efforts that are designed to stop any forward progress.

\section{Shared Vision}

Vision is the concept most present in the management and leadership literature. Senge describes this simply as those in an organization sharing a common, "What do we want to create" purpose. ${ }^{9}$ So often, vision is looked upon as merely the vision statement - the political slogan that is trotted out for donors and gracing the annual report.

\section{Team Learning}

Team learning is predicated on three requirements within the organization: 1) "to think insightfully about complex issues;" 2) "innovative, coordinated action"; and 3) "the role of team members on other teams." All three allow learning and discovery to filter throughout the organization like a web.

\section{Systems Thinking (which is the fifth discipline)}

This is an understanding of an organization and how it functions from the subunits up to the larger whole. The interactions at all levels must work together to achieve the goals of the organization.

Each of these elements is complex and requires a lot of intention and commitment to achieve. Once accomplished, they result in an organization that is agile and able to continually transform itself in response to both internal and external drivers. This is what an organization that has innovation at its core looks like.

\section{Notes}

1. Beth McMurtrie, "The Hope and Hype of the Academic Innovation Center," Chronicle of Higher Education (January 21, 2018), available online http://www.chronicle.com/article/TheHopeHype-of-the/242284 [accessed 6 April 2018].

2. Stewart Brand and R. E. Crandall, "The Media Lab: Inventing the Future at MIT," Computers 


\section{Editorial 441}

in Physics 2, no. 1 (1988): 91-92, doi:10.1063/1.4822669.

3. Everett M. Rogers, Diffusion of Innovations (New York: Simon and Schuster, 2010).

4. Rogers, Diffusion of Innovations, 281-283.

5. Johannes Haushofer, "CV of Failures," available online at https://www.princeton.edu/ joha/ Johannes_Haushofer_CV_of_Failures.pdf [accessed 6 April 2018].

6. Peter M. Senge, The Fifth Discipline: The Art and Practice of the Learning Organization (New York: Random House Business, 2006).

7. Ibid., 139.

8. Ibid., 174 .

9. Ibid., 206. 